\title{
HEAD TEACHERS' SUPERVISION OF PROFESSIONAL DEVELOPMENT AND ACADEMIC PERFORMANCE IN EMBU AND MURANGA COUNTIES, KENYA
}

\author{
Muchiri Jane Muthoni ${ }^{1}$, Margaret Wanjiru Gitumu ${ }^{2}$, John Mwaruvie ${ }^{3}$ \\ 1,2,3 Karatina University, Kenya
}

Corresponding author: jmmuthoni64@gmail.com

\begin{tabular}{ll}
\hline & Article Info \\
\hline Received & $: 25$ August 2020 \\
Accepted & $: 30$ September 2020 \\
Published $: 22$ October 2020 \\
\hline
\end{tabular}

Keywords: Academic

Performance, Professional

Development, Relationship,

Supervision

\begin{abstract}
Supervision means overall duties performed by a head teacher which ensures teachers perform their expected roles in the transmission of knowledge and enhance academic performances. Academic performance in examinations has consistently declined in primary schools in Kenya and the world over. The objective of the study was to; assess the relationship between the head teacher's supervision of professional development and academic performance in Embu and Muranga counties, Kenya. The study adopted the Role theory championed by Biddle. A descriptive survey research design was used. The Target Population was 14786 and comprised of head teachers and teachers. The researchers purposefully sampled 378 public and private primary schools. Simple random sampling was used to select 256 respondents. Data were collected using questionnaires, interviews, and observation. Reliability was ascertained by a pilot study which generated a Cronbach's alpha coefficient of 0.93. Data were analysed using descriptive and inferential statistics, precisely, correlation computations. The findings of the study informed that the highest percentage of supervision 87.4percentwas the head teachers' permission for teachers to attend seminars, workshops, and conferences. The least facilitated activity was the training of teachers by subject panels 60.3 percent. There was a negative correlation between head teachers' supervision and teacher professional development in public and private primary schools, at $r=-.069<0$ and $P=0.602>0.05$. The relationship was not statistically significant. The Supervision of teacher's professional development was not strongly linked to academic performance. There should be a balance between the supervision of teacher professional
\end{abstract}

International Journal of Educational Best Practices (IJEBP)

Vol. 4 No. 2 October 2020

ISSN: 2581-0847

DOI: $10.32581 /$ ijebp.v4n2.p1-17 
development. Governments should allocate more funds towards professional development. The findings of the study will inform policy decision making in the education sector in Kenya and worldwide.

\section{INTRODUCTION}

Head teachers' supervision of professional development of teachers is central to the academic performance of learners, development of teacher skills, career development, and introduction of new curricula among others. In Canada, Jacob and Lefgren (2002) found out that through panels, seminars teachers came together and focused on the needs of learning. They also learn and the methods that help them to solve the problems as a team, resulting in improved academic performance. In addition, they emphasized that policymakers and the community had the responsibility of ensuring that their schools are engaged in continuous teacher professional development. Head teachers' supervision of professional development is a process that embraces activities that enhance teachers' professional career growth (Regan \& Grayson, 2004; Tecle, 2006). Head teachers' supervision of professional development is aimed at promoting pupils' academic performance. Teachers' professional development activities are planned to increase teachers' competencies, knowledge, skills, and attitudes needed by school teachers in order to improve their assigned roles in the school. Guskey, (2000) in a Chinese study finding asserted that Head teachers' supervision of teachers' professional development was systematic efforts made to bring about changes in the classroom practices of teachers in their attitudes, beliefs, and in learning outcomes. It is meant to enhance teachers' professional skills, attitude, create better schools and improve the teaching /learning processes (Guskey, 2000), hence the need for emphasis on head teachers' supervision of professional development and the assessment of its relationship with academic performance.

Head teachers' supervision of professional development provides an opportunity for teachers to explore new roles, develop new instructional techniques and refine their practices and broadens themselves both as educators and individuals (Galawa, 2001 Rogan, 2004,). Mosha, (2006) in a study carried out in Tanzania, opined that head teachers' supervision of professional development had a positive impact on teachers because it kept them informed of the new dynamics in education and theories in teaching and learning hence culminating in improved pupils' academic performance. The effectiveness of teachers depends on various factors, for example; academic competencies, pedagogically, efficiency, ability, workload, and commitment (Rogan, 2004; Mosha, 2006). The head

International Journal of Educational Best Practices (IJEBP)

Vol. 4 No. 2 October 2020

ISSN: 2581-0847

DOI: $10.32581 /$ ijebp.v4n2.p1-17 
teacher supervises professional development by initiating short term training program and seminars aimed at meeting various professional needs of the teaching forces. Nndowiseni (2012) suggested that teachers need to adopt a Continual Self-renewal strategy. He further argued that Continual Self-renewal strategy ensures that the teachers remain on the cutting edge of new development as well as promoting quality in the delivery of content. According to Timperley (2008) in a research study on the role of the university in improving teachers professional development in china, opined that it had a positive impact on the development of new concepts and skills related to desired pupils academic performances.

Head teachers' supervision of teachers' professional development is a significant mechanism of advancing teachers' classroom teaching and promoting pupils' academic performance. Birman (2007) opined that to improve and facilitate teachers' competency of the subject delivery, teachers' development should be sustainable, thorough and focused on subject content with an objective of creating a positive long-lasting effect on classroom delivery and teachers performance. Birman (2007) further said that teachers who had been supervised on professional development were associated with good pupils' academic performance. The high performance was attributed to the advancement of teacher's knowledge and skills; classroom teaching affected through acquired knowledge and skills and pupils' achievement is raised by the improved teaching methodology. Therefore there is a need to invest regularly in the head teachers' supervision of professional development of teachers for effective self-appraisal on contemporary trends in teaching and learning.

Head teachers' supervision of professional development takes a variety of forms. Richardson and Orphanos (2009), Darling-Hammond (2000), opined that the supervision can be derived from formal mentoring programs developed in situ. For example, the pieces of advice teachers get from head teachers or education officers or formal meetings are held at school levels and cluster levels to review and reflect on practices on the regular basis. Established and effective utilization of teachers' resource centres is also an important element in the supervision of teachers' professional development. Kruse and Luis (1997), and Quinn and Routine; (1996) suggested that in-service training could be organized at school level clusters, where qualified senior teachers or other resource persons would be invited to serve as trainer and mentors, which would improve head teachers' supervision of teacher professional development at minimal or no cost.

Team work is important in enhancing the effect of the head teachers' supervision of teacher professional development on learning outcomes. Darling Hummond (2003) in his study findings, indicated that teachers learn best by studying, doing, and reflecting, collaborating with other teachers, and by sharing what they see. He suggested that planning for panel meetings was an effective way of enhancing head teachers' supervision of teacher

International Journal of Educational Best Practices (IJEBP)

Vol. 4 No. 2 October 2020

ISSN: 2581-0847

DOI: $10.32581 /$ ijebp.v4n2.p1-17 
professional development since it is inquiry-based and allows teachers to investigate their own methodologies used in the delivery of content to learners. It is aimed at the improvement of teaching and learning in school and it leads to deliberate and planned conditions of teaching and learning. Collaboration widens experiences and gives deeper insights as they share greater knowledge of participants and makes concepts and ideas clear to teachers. Teamwork helps teachers to evaluate themselves, organize themselves, and changes their perspectives, hence culminating in boosting school performance as well as pupil's academic performance. A study in Islamabad by Rahman (2011) observed that head teacher supervision of teacher professional development was related to effective teaching in terms of pupil's academic performance. The sample size constituted of 80 teachers and 180 students. The tool for data collection for both respondents was a questionnaire. The findings of the study were that head teacher supervision of teacher professional development had a positive relationship with pupils' academic performance. It was deduced that teachers' professional development was positively related to effective teaching resulting in good pupils' academic performance. Various studies postulate that there is a positive correlation between head teachers' supervision of teachers' professional development and pupils' academic performance. Duke (1997) and Bushman \& Bell (2001) in their study on the staff development program in Aibermale county public school in the United States observed that head teachers' supervision of teachers' professional development was able to raise the academic performance of the weak pupils by $50 \%$, which was quite encouraging.

In Botswana, in a study carried by Pansiri (2008) on the influence of head teachers' supervision of professional development on student achievement, the teachers who participated indicated that their supervisors run school-based workshops to address the curriculum needs of teachers and enhance professional development. Another group of 73\% of teachers who participated in the same study said they were supervised on professional development through workshops (Pansiri, 2008). The Nigerian National Policy on Education asserts that the educational system cannot grow beyond the quality of its teachers (Federal Republic of Nigeria, 2004). As a result, school head teachers in Nigeria ensure that they employ effective supervision of teachers' professional development. The core purpose was to monitor the implementation of curricula and ensure a desirable increase in teacher capabilities. It was also aimed at upgrading teachers' conceptual knowledge and teaching skills as well as supporting them in their work in order to improve teachers' methodological techniques and pupils' academic performance. Head teachers 'supervision on teachers' professional development cannot be separated from their pupils' performance (Odhiambo, 2005). It is therefore crucial that the government, through head teachers, ensure that head teachers' supervision of professional development is given a central place in learning institutions.

International Journal of Educational Best Practices (IJEBP)

Vol. 4 No. 2 October 2020

ISSN: 2581-0847

DOI: $10.32581 /$ ijebp.v4n2.p1-17 
Musungu \& Nasongo (2008) in Kenya found out that the head teacher supervision of teacher professional development was perceived as one of the most effective means to improve teachers' professional skills, attitudes and create better schools hence resulting in improved pupils' academic performance. The head teacher is an agent appointed by the Teachers Service Commission (TSC) entrusted with the overall supervision of teacher professional development for the purpose of improving and maintaining high teaching and learning standards in school.

The primary school head teacher supervisory role is primarily meant to help teachers improve instructional performance with the intent of improving pupils' academic performance (Okumbe, 2007). Head teacher supervision of teacher professional development, therefore, promotes the capacity building of teachers and the organization that brings a teacher's behavioural change resulting in better developmental life for the teachers' improvement of pupils and their learning hence, improved academic performance. To facilitate supervision, the head teachers occasionally attend in-service training courses and workshops which are intended to improve their supervisory task hence improving pupils' academic performance. This study intended to fill the gap by evaluating the relationship between head teachers' supervision of professional development of teachers and academic performance in public and private primary schools in Embu and Murang'a counties.

\section{OBJECTIVE OF THE STUDY}

The specific objective was to evaluate the relationship between the head teacher's supervision of professional development and academic performance in Embu and Muranga counties, Kenya

\section{HYPOTHESIS OF THE STUDY;}

There is no statistically significant relationship between head teachers' supervision of teachers' professional development and students' academic performance.

International Journal of Educational Best Practices (IJEBP)

Vol. 4 No. 2 October 2020

ISSN: 2581-0847

DOI: $10.32581 /$ ijebp.v4n2.p1-17 


\section{METHODOLOGY}

Supervision refers to responsibility of monitoring and evaluating teachers' activities and programs in the school to ensure dutiful compliance of all teachers with established laws and declared goals them. The study purposed to evaluate the relationship between the head teacher's supervision of professional development and academic performance in Embu and Muranga counties, Kenya. It had been hypothesized that there is no statistically significant relationship between head teachers' supervision of teachers' professional development and students' academic performance. The study employed a descriptive survey research design. The target population was 14786 individuals. The researcher further employed purposive, simple random and stratified random sampling procedures. The researcher picked $20 \%$ of the teachers from the sampled school (Mugenda and Mugenda, 2009) views that a representative sample is one that consists of at least $10-30 \%$ of the population of interest and is enough for providing the required information. Using simple random sampling technique; three (3) teachers per school were selected yielding to a sample of 192 teachers and 64 head teachers making a total of 256 respondents. The descriptive statistics was used to analyse data, hence computation of frequencies, percentages, means and standard deviations. Inferential statistics was also used to compare relationships between variables. The results were presented using means, percentages, figures tables and discussions.

\section{RESEARCH TOOLS}

Data was collected using questionnaires, interview schedules and observation checklists as recommended (Creswell, 2003).Validity was ascertained by experts in the education department. To establish the reliability of the research instruments a pilot study was conducted. The reliability of the tools was computed using Cronbach's alpha coefficient which yielded a threshold of 0.93 which was within acceptable limits.

\section{FINDINGS AND DISCUSSION}

The study sought to explore the extent to which head teachers supervise teachers' professional development in primary schools. Teachers were provided with a likert scale opinions on head teachers supervision on teacher professional development. They were asked to indicate the extent to which they agreed or disagree with the statement displayed

International Journal of Educational Best Practices (IJEBP)

Vol. 4 No. 2 October 2020

ISSN: 2581-0847

DOI: $10.32581 /$ ijebp.v4n2.p1-17 
in table 2 on a scale 1 to 5 where $1=$ strongly disagreed (SD), 2=Disagree (D), 3=Neutral (N) 4=Agree (A) 5=Strongly Agree (SA). For the purposes of this study the researcher collapsed strongly disagreed and disagreed to "disagree", strongly agree and agree to,. "Agree" and neutral to "undecided". Responses obtained were further used to compute a mean score $(\bar{x})$ and standard deviation(s) for each statement. The mean scores of the teachers' responses were computed on a scale of 1 to 5 . The maximum mean score was 5 while the minimum was 1 , the scores were interpreted as follows, disagreed (1.00-2.33), undecided (2.34-3.66) and agreed (3.67-5.00). Responses are indicated in table 1. A descriptive analysis from head teachers' qualitative data gathered during interview and findings from observation checklist were also discussed. The responses summarized in Table 1

Table 1. Teachers' opinions on head teachers' supervision of professional development.

\begin{tabular}{|c|c|c|c|c|c|c|c|c|c|}
\hline \multicolumn{2}{|l|}{ Statement } & \multirow{2}{*}{$\begin{array}{r}\text { SD } \\
0\end{array}$} & \multirow{2}{*}{$\begin{array}{c}\text { D } \\
10\end{array}$} & \multirow{2}{*}{$\frac{\mathbf{N}}{17}$} & \multirow{2}{*}{$\begin{array}{c}\mathbf{A} \\
70\end{array}$} & \multirow{2}{*}{$\frac{\text { SA }}{62}$} & $\mathbf{n}$ & $\bar{x}$ & $\mathbf{S}$ \\
\hline My head teacher ensures that & $\mathrm{f}$ & & & & & & & & \\
\hline $\begin{array}{l}\text { teachers forms subjects' panel } \\
\text { in school and ensure they meet } \\
\text { regularly }\end{array}$ & $\%$ & 0 & 6.3 & 10.7 & 44.0 & 39.0 & 159 & 4.16 & .85 \\
\hline $\begin{array}{l}\text { My head teacher facilitates } \\
\text { teachers who wish to enrol for }\end{array}$ & $\mathrm{f}$ & 6 & 17 & 28 & 68 & 8 & 129 & 3.73 & 1.06 \\
\hline in-service training courses & $\%$ & 3.8 & 10.8 & 17.8 & 43.3 & 24.2 & & & \\
\hline The head teacher organizes & $\mathrm{f}$ & 0 & 14 & 19 & 74 & 51 & & & \\
\hline $\begin{array}{l}\text { induction and orientation } \\
\text { programs for new teachers } \\
\text { into the school curriculum }\end{array}$ & $\%$ & 0 & 8.8 & 12.0 & 446.8 & 32.3 & 158 & 4.03 & .90 \\
\hline My head teacher gives & $\mathrm{f}$ & 2 & 6 & 12 & 67 & 72 & & & \\
\hline $\begin{array}{l}\text { permission to teachers to } \\
\text { attend seminars conferences } \\
\text { and workshops }\end{array}$ & $\%$ & 1.3 & 3.8 & 7.5 & 42.1 & 45.3 & 159 & 4.26 & .54 \\
\hline $\begin{array}{l}\text { My head teacher promptly } \\
\text { conveys information to }\end{array}$ & $\mathrm{f}$ & 2 & 13 & 20 & 73 & 51 & & & \\
\hline $\begin{array}{l}\text { teachers pertaining to further } \\
\text { training }\end{array}$ & $\%$ & 1.3 & 8.2 & 12.6 & 45.9 & 32.1 & 159 & 3.99 & .95 \\
\hline My head teacher facilitates & $\mathrm{f}$ & 55 & 18 & 30 & 63 & 42 & & & \\
\hline $\begin{array}{l}\text { teachers for bench-marking } \\
\text { with neighbouring schools }\end{array}$ & $\%$ & 3.1 & 11.3 & 19.0 & 39.9 & 26.6 & 208 & 3.75 & 1.07 \\
\hline $\begin{array}{l}\text { My head teacher provides } \\
\text { teachers with an opportunity }\end{array}$ & $\mathrm{f}$ & 8 & 17 & 24 & 68 & 41 & & & \\
\hline $\begin{array}{l}\text { for training others through } \\
\text { seminars }\end{array}$ & $\%$ & 5.1 & 10.8 & 15.2 & 43.0 & 25.9 & 158 & 3.74 & 1.11 \\
\hline
\end{tabular}

International Journal of Educational Best Practices (IJEBP)

Vol. 4 No. 2 October 2020

ISSN: 2581-0847

DOI: 10.32581/ijebp.v4n2.p1-17 
My head teacher facilitates subject specialist to the school to train teachers on KNEC marking procedures

$\begin{array}{rrrrrrr}\mathrm{f} & 8 & 15 & 40 & 57 & 39 & \\ \% & 5.0 & 9.4 & 25.2 & 35.8 & 24.5 & 159 \\ & & & & & & \end{array}$

3.65

The findings from Table 1 indicated that the majority of the respondents (83\%) agreed that their head teachers ensured that teacher's formed subject panel in school and ensured they meet regularly. on the other hand a minority $6.3 \%$ of the respondents disagreed while $10.7 \%$ were undecided to the statement. The mean score and standard deviation $(\overline{\boldsymbol{x}}=4.16$, $\mathrm{s}=.87$ ) for this statement indicated that the teachers were generally in agreement with the statement that the head teachers ensured that teachers formed subject panels in their schools. The findings from the interview schedule supported the results from the questionnaires. For example a head teacher from private school during an interview affirmed: HT 1:

"In my school subject panel meetings were held on a weekly basis to comment on areas of correction and improvement. A lot of subject in-depth is discussed".

This finding is consistent with assertions of Darling Hummond (2003) in his study findings who observed that teachers learn best by studying, doing and reflecting by collaborating with other teachers and by sharing what they see. He suggested that panel meetings are effective teacher professional development since it is inquiry based and allows teachers to investigate their own worlds. It is aimed at improvement of teaching and learning in school and it leads to deliberate and planned conditions of teaching and learning. Collaboration has a lot of value. It widens experiences and gives deeper insights as they share greater knowledge of participants and make concepts and ideas tick in teachers mind hence promoting pupils academic performance. Teamwork helps teachers to evaluate themselves, organize themselves and change their perspectives hence culminating in boosting schools performance as well as pupil's academic performance. However the findings were not collectively positive. Data from an interviewee indicated that some subject panels are not active. One head teacher from a public school in Embu explained; HT 2:

"In my school subject panels are dormant; teachers' do not meet because they are overloaded with an average of 40 to 43 lessons per week. The time scheduled for them to meet after class per department is when they are busy writing lesson notes and lesson plans for the next day. This leaves them with no time for subject panel meeting s".

International Journal of Educational Best Practices (IJEBP)

Vol. 4 No. 2 October 2020

ISSN: 2581-0847

DOI: $10.32581 /$ ijebp.v4n2.p1-17 
The findings were further evident from the observation checklist results that revealed that most of the subject panels were not functional. There were no recent subjects' panel minutes. Those who had met were probably a year ago, mostly only a list of subject panellists was hanged in the head teacher's office. This means the head teachers did not supervise their implementation. This finding reveals that head teachers are not thorough in supervision of teachers' participation in subject panels. Hence the head teachers expressed that despite its vitality it faces a lot of hiccups to be scheduled in busy school days as teachers are overloaded with other school program mostly teaching rendering some not to implement what is learn resulting to poor performance .Teachers stagnant for lack of sharing knowledge .Failure by some schools to have subject panels could be a reason for low performance.

The opinions of teachers were sought on the statement 'My head teacher facilitates teachers who wish to attend in-service training courses'. The findings in table were generally positive with the majority of teachers (68 percent) agreeing that their head teachers facilitate in-service training and only 14.6 percent disagreed while 17.8 percent being undecided this view. The mean score $(\overline{\boldsymbol{x}}=3.73, \mathrm{~s}=1.06)$ suggested that teachers were on a general scale in agreement with the statement. This implies the head teacher supervises the professional growth of teachers for they know its impact. The findings are consistent with the assertion of Mosha, (2006) study in Tanzania that head teachers' supervision of teachers' professional development has a positive impact on teachers because it keeps them informed of the new dynamics in education and theories in teaching and learning hence resulting to improvement in pupils' academic performance. The findings further revealed that the majority (79.1 percent) of teachers has a positive view on their head teachers organizes induction and orientation programs for new teachers into the school curriculum while those who did not believe that head teachers inducted new teachers made up 20.9 percent. This implies that the teachers do not encounter problems in carrying their roles since they are mentored and are conversant with school systems. The questionnaires findings were supported by findings from interview schedules .A head teacher interviewed ascertained; HT3:

"After hiring a new teacher, we attach her or him to a teacher in the department to coach and mentor her on schools programs, traditions and schools' academic expectations"

This implies head teachers supervision in this area is adequately done. The respondents generally accord with the opinions presented by the researcher in the Likert scale as can be seen in the statement 'My head teacher grants study leave for teachers who want to enrol for post graduate studies' where majority of the teachers (62.9 percent) concurred while partly a quarter (25.2 percent) of the sampled teachers were refuted, 11.9 percent dissented that head teachers give teachers leave to enrol in post graduate studies. This implies that the

International Journal of Educational Best Practices (IJEBP)

Vol. 4 No. 2 October 2020

ISSN: 2581-0847

DOI: $10.32581 /$ ijebp.v4n2.p1-17 
majority of the teachers (62.9 percent) felt that head teachers support teachers who want to enrol for further studies. This can be interpreted that head teachers know the value of higher academic empowerment of teachers which would result to improving pupils' performance. The study findings were in line with assertions of Nndowiseni (2012) in his study who suggested that teachers need to adopt a Continual Self renewal strategy. He further argued that Continual Self-renewal strategy ensure that the teachers remain on the cutting edge of new development as well as promoting his/her quality resulting to improving pupils academic performance.

The findings concur with MOEST (2003) views that formal education and teacher training acquisition are positively correlated with teachers' knowledge and their ability to impart knowledge to pupils leading to improvement in academic performance. However from the study findings despite the value of furthering studies a good number of teachers 37 percent had not furthered their studies thus could be a result for dismal pupils' performance in the area of study. Similarly the researcher wanted to establish whether the head teachers also support teacher's professional development by giving them opportunities to train others through seminars. The findings indicated that majority of the sampled teachers (68.9 percent) opinions strongly concurred with the statement while (15.2 percent) were neutral and 15.9 percent were not in favour with the opinion. This implies that head teachers put in efforts to supervise their teachers professionally by allowing them to attend seminars.

These findings were consistent with the assertion of Mugambi (2018) that School leaders focused on pupils' results outcome are able to create the condition that makes effective teaching and learning possible. High performing system puts the energy upfront in recruiting and supporting high quality teachers. However some teachers are appointed to attend seminars involuntary thus when they come back to schools they don't share with others since they don't see it as their program. This finding corroborate with Timperley (2008) research in china who urged that in seminar external expertise will be effective only when it involves teachers' discussion and understanding about what is meaningful in their particular working otherwise despite the attendance performance remains dismal. However the study findings show that about $30 \%$ of the sampled teachers do not attend seminars which could be detrimental to teachers' development leading to low performance. The findings were supported by teachers' qualitative data when they were asked to comment on how pupils' academic performance would be improved. A teacher; T1 responded:

"More teachers should be given chance to attend seminars unlike where head teacher repeatedly selects some teacher to attend seminars, mainly teachers attending standard eight candidates, denying others chances mainly those in middle and lower classes signifying poor head teacher supervision".

International Journal of Educational Best Practices (IJEBP)

Vol. 4 No. 2 October 2020

ISSN: 2581-0847

DOI: $10.32581 /$ ijebp.v4n2.p1-17 
Another teacher, T2 said:

"A number of teachers suggested appointment to seminar attendance should be accorded to all teachers irrespective of class and level."

These findings are is in line with assertions of Kenya Education Staff Institute (KESI, 2011) recommendation that for primary schools to provide quality education through, high performance in KCPE, head teachers as internal supervisors are supposed to ensure that staff in service training is carried out in a coordinated manner to benefit all teachers.

The teachers views were supported by a head teacher's assertion during an interview where one head teachers decried; HT4:

"In public schools most, head teachers are not able to facilitate many teachers for seminar due to financial constraints."

The above findings indicated that not all head teachers supervise teachers' professional development and this could have negatively impacted teachers' professional growth as well as pupils' performance in KCPE examination in Embu and Muranga counties. These findings corroborate the assertions of Okumbe (2007) that no teacher can claim to be fully equipped in knowledge sufficient to last him through his/her teaching career. They require continuous upgrading. The findings would imply the head teachers contradicts the commission (TSC,2015) section 52 of code of regulation that stipulates head teachers of education institution to supervise and identify teacher's development needs in line with global innovations in order to boost pupil's performance. Moreover the researcher enquired if head teachers facilitates subject specialist to the school to help train teachers on KNEC marking procedures. The study established that majority of the sampled teachers 60.3 percent affirm the statement while 25.2 percent were neutral, and the rest 14.4 percent did not agree with this perspective. This means about 40 percent of the sampled teachers do not have an opportunity to be facilitated by the head teachers.

The respondents (66.5 percent) claimed that their head teacher facilitates teachers for benchmarking with neighbouring schools. However, this view was not held by all the respondents as 14.4 percent of the respondents disagreed while the other 19 percent were undecided on the statement. The mean score and standard deviation for this statement $(\bar{x}=$ $4.26, \mathrm{~s}=.54)$ revealed that the teachers were generally in agreement that the head teacher facilitated teachers for benchmarking with neighboring schools. However, it is important to note the high level of variation in some of the responses is an indication of inconsistent feeling of teachers with the head teachers' supervision role on teacher professional

International Journal of Educational Best Practices (IJEBP)

Vol. 4 No. 2 October 2020

ISSN: 2581-0847

DOI: $10.32581 /$ ijebp.v4n2.p1-17 
development. Implying head teachers' supervision on teachers was an issue needing address. . This was supported by a teacher qualitative data whereby T3 said:

"They needed to be facilitated to attend bench marking, where their schools would visit high performing schools and have an opportunity to share, discuss and learn from them on strategies and skills to employ in order to improve pupils' performance in their schools".

These findings were in agreement with Kruse et.al (1997), and Quinn and Restine (1996) supported that training can be organized at school level cluster where qualified senior teachers or other resource persons would be invited to serve as trainer and mentors. The interactive, on job coaching and mentoring lead to teacher professional development and in cost effective. Such formal arrangement promotes team teaching, sharing of experiences and educational resources among teachers which greatly contribute to self-development enhancing teachers competences. When teachers apply the knowledge gained it results to improving pupils' academic performance. Findings in the area of studies shows benching marking is an issue to be addressed and therefore deduced as to be a cause of dismal performance in both Embu and Muranga counties.

Generally, the teachers agreed that the head teachers support their professional growth. The findings are in consistence with assertions of Okumbe (2007) that the broad goal of supervision as catalysts of improving teachers' professional growth is providing teachers with objective feedback on the current rate of their instruction, help in diagnosing and solving instructional problems, assisting them develop skills in using instructional techniques and acquiring a positive perspective about continuous professional growth. The findings were also in agreement with Zepeda (2003) views that head teacher supervision promotes capacity building of the individual (teacher) and the organization that brings a teacher's behavioural change resulting to better developmental life for the teachers improve pupils and their learning, hence realizing good academic performance.

Figure 1 provides further illustration on perceptions of teachers on head teachers' supervision of teachers' professional development in Embu and Murang'a Counties. The table gives teachers' responses to the questionnaire and results are indicated in form of percentages against the 8 items in the questionnaire.

International Journal of Educational Best Practices (IJEBP)

Vol. 4 No. 2 October 2020

ISSN: 2581-0847

DOI: $10.32581 /$ ijebp.v4n2.p1-17 


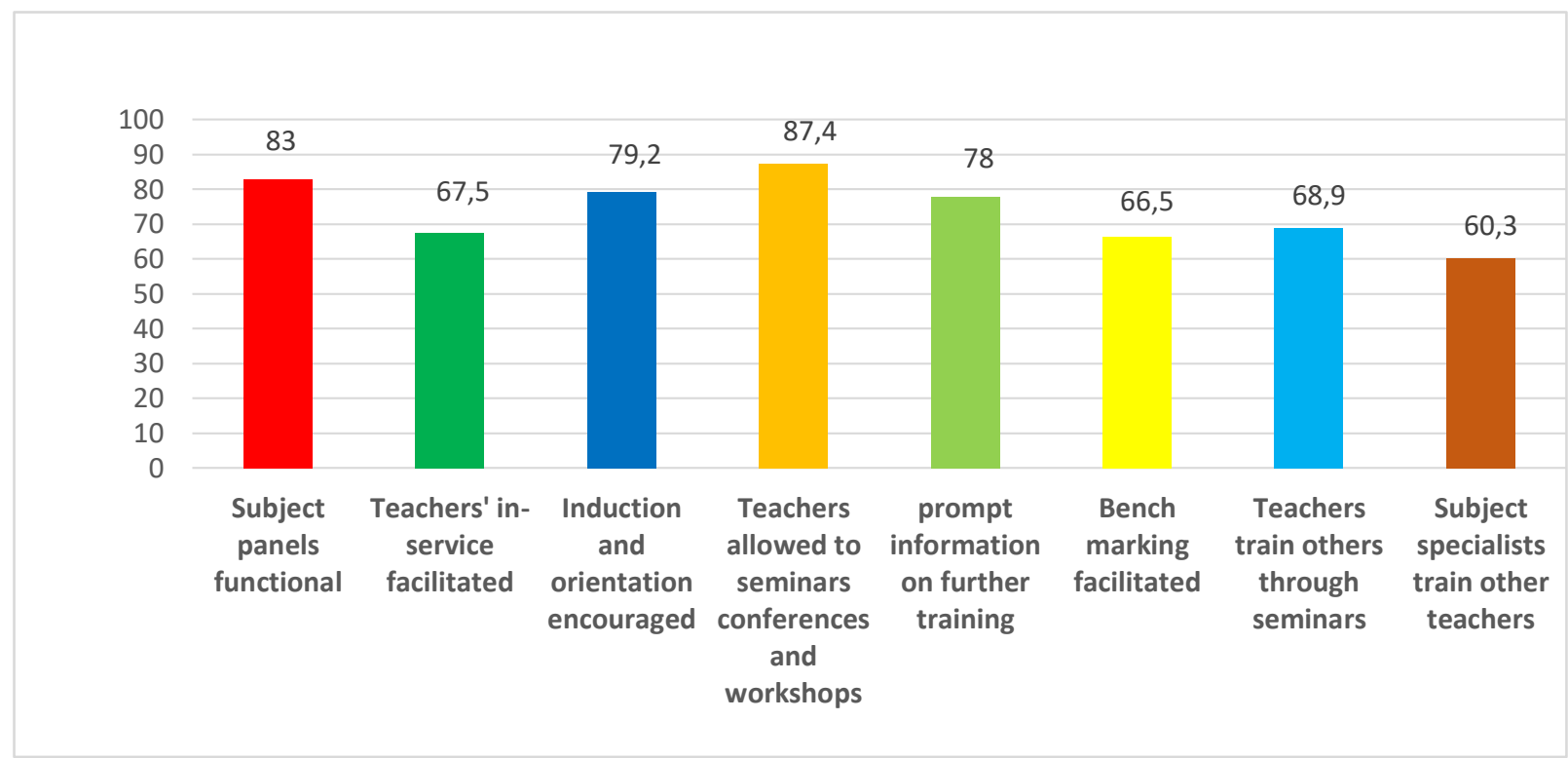

Figure 1: Teachers' opinions on head teachers' supervision of professional development.

Figure 1 shows that the highest percentage of teachers' responses was the provision of permission to teachers to attend organized seminars, workshops and conferences aimed at enhancing their professional development ( 87.4 percent). The second best responses were on activeness of subject panels. Responses show that teachers were encouraged to form subject panels (83 percent), to enhance their professional development which would in turn improve the academic performance of learners. The least facilitated activity was the provision of chances for subject specialists to train teachers (60.3 percent). This means that head teachers need to improve their supervision in this aspect, which expected to enhance the professional development of teachers hence lead to improved academic performance of pupils. Facilitation of benchmarking of teachers (66.5 percent) and teachers' in-service initiatives were other aspects that needed attention for them to be closer to the well done supervised activities.

The study further tested the null hypothesis; there is no statistically significant relationship between head teachers' supervision of teachers' professional development and academic performance. Results were computed by computing chi-square values to determine the relationship that existed between head teachers' supervision and academic performance in Embu and Murang'a sub-counties. Results were presented in table 2

International Journal of Educational Best Practices (IJEBP)

Vol. 4 No. 2 October 2020

ISSN: 2581-0847

DOI: $10.32581 /$ ijebp.v4n2.p1-17 
Table 2. Relationship between head teachers supervision of professional development and KCPE performance

\begin{tabular}{|c|c|c|c|}
\hline & & $\begin{array}{c}\text { KCPE } \\
\text { Performance }\end{array}$ & $\begin{array}{c}\text { Supervision of } \\
\text { teachers' } \\
\text { professional } \\
\text { development }\end{array}$ \\
\hline \multirow{4}{*}{ KCPE Performance } & Pearson Correlation & 1 & -.069 \\
\hline & Sig. (2-tailed) & & .602 \\
\hline & $\mathrm{N}$ & 62 & 60 \\
\hline & Pearson Correlation & -.069 & 1 \\
\hline $\begin{array}{l}\text { Supervision of teachers' } \\
\text { professional development }\end{array}$ & $\begin{array}{l}\text { Sig. (2-tailed) } \\
\mathrm{N}\end{array}$ & $\begin{array}{r}.602 \\
60\end{array}$ & 154 \\
\hline
\end{tabular}

The findings in table 2 reveals a negative correlation exists between head teacher's supervision of teacher's professional development and public and private primary school performance $(r=-.069<0$, and $\mathrm{p}=0.602>0.05)$. This implies that a decreasing relationship exists between supervision of professional development of teachers and school performance. The relationship was however, not statistically significant at $\mathrm{p}=0.602$ which was higher than the significant threshold of 0.05. This implies that the researcher fails to reject the null hypothesis that, 'Head teachers' supervision on teacher's professional development has no statistically significant relationship on academic performance in public and private primary schools in Embu and Murang'a Counties' Therefore, the findings indicate that supervision of teachers professional development leads to decline in the performance of primary schools in the counties. This finding contradicted several authors who postulate that there was a correlation between teacher's professional development and pupils' academic performance. Duke (1987); Bushman and Bell (2001)in their research study on staff development program in Alabama county public school in United States observed that in teachers professional development was able to raise academic performance of the poor pupils by 50\%.In Botswana the study carried by Pansiri(2008) Similarly in a study carried by Pansiri (2008) in Botswana on influence of head teachers on instructional supervision and students achievement, observed the teachers who participated indicated that their supervisors run school-based workshops to address the curriculum needs of teachers. Lending to higher performance

Based on the findings of the study, the most indicator of head teachers' supervision of teachers' professional development was the head teachers' provision of permission for teachers to attend seminars, conferences and workshops (87.4 percent). This implies that most head teachers give their teachers permission to attend designated forums which promote their professional development. Apart from forums, teachers were encouraged to

International Journal of Educational Best Practices (IJEBP)

Vol. 4 No. 2 October 2020

ISSN: $2581-0847$

DOI: $10.32581 /$ ijebp.v4n2.p1-17 
form subject panels, which were functional as per teachers' perceptions ( 83 percent). The least indicator of head teachers' supervision of teachers' professional development was the facilitation of subject specialists to train teachers, as indicated by 60 percent of respondents. The other aspect of low supervision by head teachers was facilitation of bench-marking of teachers. This was followed by the facilitation of teachers for bench marking and reflected by 66.5 percent of respondents. This implies that head teachers need improve in the two aspects of supervision of teachers' professional development. Results also revealed that a negative correlation existed between head teacher's supervision and academic performance $(\mathrm{r}=-.069<0$, and $\mathrm{p}=0.602>0.05)$. This implies that a decreasing relationship existed between supervision of teachers and school academic performance. The relationship is however, not statistically significant at $\mathrm{p}=0.602$ which is higher than the significant threshold of 0.05 .

\section{CONCLUSIONS}

The study aimed at exploring the extent to which head teachers supervise teachers' professional development in primary schools. It is important that head teachers develop a balance between supervisory roles and leadership to enhance teacher motivation to improve academic performance. Professional development was found to be done by majority of the head teachers by granting permission and leave for teachers to attend post graduate studies, seminars and workshops. Through this measure, head teachers allow the teachers to grow their knowledge and scope which helps improve their delivery of content ultimately improving performance. However, the teachers complained of head teachers selectively appointing teachers continually hence locking others out of growth. They requested for more seminars for all subjects and bench-marking. It was also observed that subject panels were non-operational in most schools they need to be revived and operational.

\section{REFERENCES}

Creswell, J.W. (2003). Research design: Qualitative, Quantitative and mixed methods Approaches ( $2^{\text {nd }}$ ed.). Thousand Oaks, CA: Sage Publication, Inc.

Duke, D.L. (1987). School Leadership \& Institutional Improvement. New York: Random House.

Earley, P. (1998 ed). School Improvement after Inspection? School and LEA Responses. London: Paul Chapman publishing Ltd.

International Journal of Educational Best Practices (IJEBP)

Vol. 4 No. 2 October 2020

ISSN: 2581-0847

DOI: 10.32581/ijebp.v4n2.p1-17 
Ehren, M \& Visscher, A. (2006). Towards a Theory on the Impact of School Inspections. British Journal of Educational Studies 54 (1), 51-72

Fisher, C. F. (2005). A new Agenda for Research in Educational leadership. Amazon.com/adminbook.3html. December 25.

Grauwe, A. (2007). Transforming School Supervision into a tool for quality improvement. Journal of International Review of Education 53 (3), 709-714.

Hoyle, E \& Wallace, M. (2005). Educational Leadership; Ambiguity .Professional and Managerialism. London: SAGE Publication.

Kruse, S. D. \& Louis, K. S. (1997). Teaching Teaming in Middle Schools: dilemmas for a School-widecommunity. Educational administration quarterly 33 (3), 57-71.

Kenya Education Staff Institute (2011) Nairobi, Government printer.

MOEST (2003). Report of the sector review and development. Nairobi, Government Printer.

Mosha, H. J. (2006). Capacity of school management for Teacher Professional Development In Tanzania. Address. Delivered at a workshop on the Role of universities in promoting basic educationin Tanzania, held at the Millenium Towers Hotel, Dar es Salaam,Tanzania, May 19

Mugambi,H., (2018). Quality Education in Kenya needs Quality Teacher Daily Oct.26 ${ }^{\text {th }}$ 2018 www.Standardmedia.Co.ke.

Mugenda, A. \& Mugenda, O. (2009).Research methods, Quantitative and Qualitative Approaches. Acts Press Nairobi.

Musungu L.L \& Nasongo J. W (2008). The head teachers' role in academic achievement in secondary schools in Vihiga District, Kenya: Education Printers.

Nndowiseni A. R. (2012). Assessing best practice implementation of quality assurance in basic education by establishing standards and measuring program effectiveness. Journal of Emerging Trends in Educational Research and Policy Studies3 (4) 3243.

International Journal of Educational Best Practices (IJEBP)

Vol. 4 No. 2 October 2020

ISSN: 2581-0847

DOI: $10.32581 /$ ijebp.v4n2.p1-17 
Okumbe, K. (2007). Educational Management: Theory and Practice. Nairobi: University of Nairobi Press.

Onasanya,S.A..(2006). The concept and practice of supervision and inspection in kwara state public primary school. (Unpublished M.Ed dissertation), University of Ilorin, Nigeria.

Pansiri, N.O. (2008). Instructional leadership for quality learning: An assessment of the impact of the primary school management development project in Botswana. Educational Management, Administration and Leadership 36 (4), 471-494.

Quinn, G. \& Restine, L. N. (1996). Interdisciplinary teams: concerns, benefits, and costs. Journal of school leadership 6 (4), 494-511.

Sergiovanni, T. J. \&Starratt, R. (2002).Supervision: A redefinition ( $7^{\text {th }}$ ed.). New York: McGraw-Hill.

Timperley, H. (2008). Teacher professional learning and development. The International Academy of Education.

Wilcox, Brian. (2000). Making School Inspection Visits More Effective: The English Experience. Paris: UNESCO

Zepeda, (2003). Instructional Improvement in Four African Counties, McGrawHillCompaniesInc.

International Journal of Educational Best Practices (IJEBP)

Vol. 4 No. 2 October 2020

ISSN: 2581-0847

DOI: $10.32581 /$ ijebp.v4n2.p1-17 